\title{
Microwave-assisted Acid Dissolution of Sintered Advanced Ceramics for Inductively Coupled Plasma Atomic Emission Spectrometry
}

Journal of

Analytical

Atomic

Spectrometry

\author{
MARÍA T. LARREA ${ }^{a}$, ISABEL GÓMEZ-PINILLA ${ }^{b}$ AND JUAN C. FARIÑAS*c \\ ${ }^{a}$ Centro Nacional de Investigaciones Metalúrgicas (CSIC), Avda. Gregorio del Amo 8, Ciudad Universitaria, 28040 Madrid, Spain \\ ${ }^{b}$ Centro de Espectrometría Atómica de la Universidad Complutense de Madrid, Facultad de Geológicas, Ciudad Universitaria, 28040 Madrid, Spain \\ ${ }^{c}$ Instituto de Cerámica y Vidrio (CSIC), 28500 Arganda del Rey, Madrid, Spain
}

\begin{abstract}
The microwave-assisted acid dissolution of sintered bodies of 28 structural and electronic advanced ceramic materials was systematically evaluated. These materials included zirconiabased ceramics, such as $\mathbf{m}-\mathrm{ZrO}_{2}$ (a non-stabilized monoclinic zirconia), Ca-PSZ and Mg-PSZ (two partially stabilized zirconias), Y-FSZ (a fully stabilized zirconia) and Ce-TZP, $\mathrm{Yb}-\mathrm{TZP}$ and Y-TZP/Ce (three tetragonal polycrystalline zirconias); alumina-based ceramics, such as $\mathrm{Al}_{2} \mathrm{O}_{3}$, mullite and spinel; ceria-based ceramics, such as $\mathrm{CeO}_{2}-\mathrm{Gd}_{2} \mathrm{O}_{3}$ (cubic ceria gadolinia); titania-based ceramics, such as $\mathrm{TiO}_{2}$; titanatebased ceramics, such as $\mathrm{Al}_{2} \mathrm{TiO}_{5}, \mathrm{BaTiO}_{3}$ and $\mathrm{BIT}$ (bismuth titanate); lead titanate-based ceramics, such as Ca-PT, La-PT, Nd-PT, Sm-PT and Gd-PT; lead zirconate titanatebased ceramics, such as PZT and PLZT; niobate-based ceramics, such as PMN (lead magnesium niobate); non-oxidebased ceramics, such as $\mathrm{AlN}, \mathrm{BN}, \mathrm{Si}_{3} \mathrm{~N}_{4}$ and $\mathrm{SiC}$; and oxide and non-oxide-based ceramics, such as $\beta^{\prime}$-sialon (silicon aluminium oxynitride). Fifteen acids or mixtures of acids were tried, including $\mathrm{HCl}, \mathrm{HNO}_{3}, \mathrm{H}_{2} \mathrm{SO}_{4}$, aqua regia, $\mathrm{H}_{2} \mathrm{SO}_{4}-\left(\mathrm{NH}_{4}\right)_{2} \mathrm{SO}_{4}$ and mixtures of these acids with $\mathrm{HF}$ and with $\mathrm{H}_{2} \mathrm{O}_{2}$. A commercially available laboratory medium pressure microwave oven was used. Eleven optimized microwave methods were developed. These methods are simple (three stages maximum), fast (15-35 min digestion time) and mild $(20-60 \%$ of the microwave oven power). By applying these microwave methods, it was possible to dissolve completely all the sintered advanced ceramics, except $\mathrm{SiC}$ and $\beta^{\prime}$-sialon. These two non-oxide ceramics were the only samples that could not be dissolved by any of the acids or mixtures of acids tested. The microwave-assisted acid dissolution was compared for ICP-AES with conventional dissolution procedures, i.e., alkali fusion in a platinum crucible and in a graphite crucible and acid decomposition by conductive heating at elevated pressure (in a PTFE bomb). It was demonstrated that microwave-assisted dissolution presents many advantages over the other procedures. When compared with acid decomposition by conductive heating in a PTFE bomb, one of the most important advantages is the drastic shortening of the digestion time from hours to minutes. When compared with alkali fusions, one of the most important advantages is the use of smaller amounts of high-purity acids, which contain less impurities than the fluxes; because of this, matrix effects and contamination from the attack reagents are lower, and consequently there is an improvement in the analytical figures of merit of ICP-AES.
\end{abstract}

Keywords: Microwave-assisted dissolution; structural sintered advanced ceramics; electronic sintered advanced ceramics; inductively coupled plasma atomic emission spectrometry

The terms advanced, engineering or technical ceramics refer to ceramic materials which exhibit superior mechanical proper- ties, high-temperature stability, high-temperature strength, wear resistance, corrosion/oxidation resistance, chemical inertness, or electrical, optical and/or magnetic properties. ${ }^{1}$

These materials are used in structural applications (machine and cutting tools, wear components, heat exchangers, aerospace components, automotive engine components such as turbocharge rotors and roller cam followers, power generation components, biomedical implants, processing equipment used for fabricating a variety of polymer, metal and ceramic parts) and in electronic applications (insulators, capacitors, actuators, transducers, varistors, electronic sensors and devices, oxygen sensors, temperature sensors, electrooptical elements and magnetic devices). In this way, the advanced ceramic materials can be classified into structural ceramics and electronic ceramics. These ceramics include binary oxide-based materials, such as alumina $\left(\mathrm{Al}_{2} \mathrm{O}_{3}\right)$, zirconia $\left(\mathrm{ZrO}_{2}\right)$, titania $\left(\mathrm{TiO}_{2}\right)$ and ceria $\left(\mathrm{CeO}_{2}\right)$; ternary oxide-based materials, such as mullite $\left(3 \mathrm{Al}_{2} \mathrm{O}_{3} \cdot 2 \mathrm{SiO}_{2}\right)$, spinel $\left(\mathrm{MgO} \cdot \mathrm{Al}_{2} \mathrm{O}_{3}\right)$ and aluminium titanate $\left(\mathrm{Al}_{2} \mathrm{TiO}_{5}\right)$; non-oxide-based materials, such as boron nitride $(\mathrm{BN})$, aluminium nitride $(\mathrm{AlN})$, silicon nitride $\left(\mathrm{Si}_{3} \mathrm{~N}_{4}\right)$ and silicon carbide $(\mathrm{SiC})$; perovskite-based materials, such as barium titanate $\left(\mathrm{BaTiO}_{3}\right)$, alkaline earth or rare earth elementmodified lead titanate (e.g., Ca-PT or Gd-PT), lead zirconate titanate or PZT $\left(\mathrm{PbZr}_{1-x} \mathrm{Ti}_{x} \mathrm{O}_{3}\right)$ and lanthanum-modified lead zirconate titanate or PLZT $\left(\mathrm{Pb}_{1-y} \mathrm{La}_{y} \mathrm{Zr}_{1-x} \mathrm{Ti}_{x} \mathrm{O}_{3}\right)$; and oxide and non-oxide mixed compounds, such as silicon aluminium oxynitride or $\beta^{\prime}$-sialon $\left(\mathrm{Si}_{6-x} \mathrm{Al}_{x} \mathrm{O}_{x} \mathrm{~N}_{8-x}\right)$, a set of materials based on combinations of $\mathrm{Si}_{3} \mathrm{~N}_{4}$ with $\mathrm{Al}_{2} \mathrm{O}_{3}$ and other oxides.

The properties of these materials are greatly influenced by the stoichiometric molar ratio of the macroconstituents, ${ }^{2}$ and also by the presence of impurities, ${ }^{3}$ even at very low concentrations. Furthermore, small amounts of dopants, ${ }^{4}$ sintering aids $^{5}$ and other additives ${ }^{6}$ are added to these ceramics in order to improve their processing and ultimate properties. Because of this, the determination of these elements is vital to manufacturing control, property improvement, failure prevention and quality assurance.

Inductively coupled plasma atomic emission spectrometry (ICP-AES) is nowadays the most widely used technique for the analytical characterization of advanced ceramics. It has been applied to the chemical analysis of a wide variety of samples: $\mathrm{Al}_{2} \mathrm{O}_{3},{ }^{7-10} \mathrm{ZrO}_{2}$-based materials, ${ }^{11-14} \mathrm{AlN},{ }^{9,10,12}$ $\mathrm{Si}_{3} \mathrm{~N}_{4},{ }^{9,10,15-17} \mathrm{SiC}^{9,10,18-20}$ perovskite-based materials, ${ }^{13,21}$ $\mathrm{BaTiO}_{3},{ }^{13,22,23} \mathrm{Gd}-\mathrm{PT},{ }^{13} \mathrm{PZT},{ }^{13,24}$ PLZT,${ }^{13}$ etc. For the chemical analysis of these refractory and chemically resistant materials, complete dissolution of the samples with extreme chemical treatments must be performed. This has been realized by two general procedures: acid decomposition and alkali fusion. Acid decomposition procedures include: (i) conductive heating at atmospheric pressure with $\mathrm{H}_{2} \mathrm{SO}_{4}+\mathrm{HF}$ in a platinum dish, ${ }^{25}$ $\mathrm{HCl}+\mathrm{H}_{2} \mathrm{SO}_{4}+\mathrm{HF}$ in a platinum crucible, ${ }^{14} \mathrm{H}_{2} \mathrm{SO}_{4}+$ $\left(\mathrm{NH}_{4}\right)_{2} \mathrm{SO}_{4}$ in a glass beaker ${ }^{11-13,24,26}$ or a platinum dish ${ }^{13,21}$ 
and $\mathrm{H}_{3} \mathrm{PO}_{4}+\mathrm{H}_{2} \mathrm{SO}_{4}$ in a quartz beaker, ${ }^{7}$ a PTFE beaker ${ }^{8}$ or a platinum crucible, ${ }^{27}$ and (ii) conductive heating at elevated pressure with $\mathrm{HCl},{ }^{8,12,13,21-23,25,28-31} \mathrm{HNO}_{3},{ }^{32} \mathrm{H}_{2} \mathrm{SO}_{4},{ }^{28}$ $\mathrm{HCl}+\mathrm{HNO}_{3},{ }^{9,10} \mathrm{HCl}+\mathrm{H}_{2} \mathrm{SO}_{4},{ }^{9,10,32,33} \mathrm{H}_{2} \mathrm{SO}_{4}+\mathrm{HClO}_{4},{ }^{28}$ $\mathrm{H}_{2} \mathrm{SO}_{4}+\mathrm{H}_{3} \mathrm{PO}_{4},{ }^{28} \mathrm{HF},{ }^{28,34} \mathrm{HCl}+\mathrm{HF}^{35,36}$ $\mathrm{HNO}_{3}+\mathrm{HF},{ }^{9,10,17,37,38} \mathrm{H}_{2} \mathrm{SO}_{4}+\mathrm{HF},{ }^{13,21,24,28} \mathrm{HClO}_{4}+\mathrm{HF},{ }^{28}$ $\mathrm{H}_{3} \mathrm{PO}_{4}+\mathrm{HF},{ }^{28} \mathrm{HCl}+\mathrm{HNO}_{3}+\mathrm{HF}^{26}$ $\mathrm{HNO}_{3}+\mathrm{H}_{2} \mathrm{SO}_{4}+\mathrm{HF}^{9,10,19,20,33,39,40}$ and $\mathrm{HF}+\mathrm{H}_{2} \mathrm{O}_{2}{ }^{32}$ in a PTFE bomb. Alkali fusion procedures include: (i) fusion in a platinum crucible with $\mathrm{Na}_{2} \mathrm{CO}_{3},{ }^{23,41}$ $\mathrm{Na}_{2} \mathrm{CO}_{3}+\mathrm{Na}_{2} \mathrm{~B}_{4} \mathrm{O}_{7},{ }^{12,13,21} \quad \mathrm{Na}_{2} \mathrm{CO}_{3}+\mathrm{Na}_{2} \mathrm{SO}_{4},{ }^{15}$ $\mathrm{Na}_{2} \mathrm{~B}_{4} \mathrm{O}_{7}+\mathrm{KNO}_{3},{ }^{42} \quad \mathrm{CaCO}_{3}+\mathrm{H}_{3} \mathrm{BO}_{3},{ }^{25} \mathrm{Li}_{2} \mathrm{CO}_{3}+\mathrm{H}_{3} \mathrm{BO}_{3}{ }^{7}$ and $\mathrm{Na}_{2} \mathrm{~B}_{4} \mathrm{O}_{7}+\mathrm{H}_{3} \mathrm{BO}_{3}+\mathrm{LiOH} ;{ }^{43}$ and (ii) fusion in a graphite crucible with $\mathrm{LiBO}_{2}{ }^{8}$ and $\mathrm{Li}_{2} \mathrm{~B}_{4} \mathrm{O}_{7} \cdot{ }^{13,21,23,24}$ For comparative purpose, Table 1 summarizes the literature methods using acid decomposition by conductive heating at elevated pressure in a PTFE bomb for the dissolution of advanced ceramic powders.

However, these dissolution procedures, which are a major source of errors and difficulties, present several serious disadvantages. Acid decomposition procedures are time consuming, often require the use of potentially hazardous acids and can lead to systematic errors such as contamination, loss of volatile elements and incomplete digestions. Alkali fusion procedures, although efficient and relatively rapid, are very laborious, requiring constant supervision during operation, and can also lead to the aforementioned systematic errors. In addition, the high reagent blank of the fluxes and the large dilution factor of the sample solution can lead to a decrease in the sensitivity.

The microwave-assisted heating technique ${ }^{44,45}$ is a promising alternative for sample preparation owing to the advantages over the conventional acid decomposition and alkali fusion procedures: strict control of the heating power and of the time the heating is applied, more amenable to automation, ability to use small volumes of reagents, lower reagent blank, complete digestion without the use of $\mathrm{HClO}_{4}$, extremely short digestion times, lower risk of contamination from the decomposition vessel and from the laboratory environment, no losses of volatile elements, etc.

Despite the great interest that this technique presents, only two papers ${ }^{32,46}$ devoted to their application to ceramic materials could be found. Table 2 summarizes the microwaveassisted dissolution methods used in these papers. Tatár et al. ${ }^{46}$ studied the influence of various physico-chemical properties (crystalline phase, particle size and specific surface area) of $\mathrm{Al}_{2} \mathrm{O}_{3}$ samples on efficiency of microwave-assisted digestion with $\mathrm{H}_{2} \mathrm{SO}_{4}(1+1)$ at $170{ }^{\circ} \mathrm{C}$ as a function of time. Matusiewicz $^{32}$ compared a commercial microwave-assisted digestion system with the conventional PTFE bomb decomposition for the dissolution of $\mathrm{Al}_{2} \mathrm{O}_{3}, \mathrm{AlN}, \mathrm{BN}$ and $\mathrm{Si}_{3} \mathrm{~N}_{4}$ samples. However, all the samples in both studies were commercial

Table 1 Summary of literature methods using acid decomposition by conductive heating at elevated pressure in a PTFE bomb for the dissolution of advanced ceramic powders

\begin{tabular}{|c|c|c|c|c|c|}
\hline $\begin{array}{l}\text { Ceramic } \\
\text { powder }\end{array}$ & $\begin{array}{l}\text { Sample mass/ } \\
\text { mg }\end{array}$ & $\begin{array}{l}\text { Acid or mixture of acids/ } \\
\mathrm{ml}\end{array}$ & $\begin{array}{c}\text { Temperature/ } \\
{ }^{\circ} \mathrm{C}\end{array}$ & $\underset{\mathrm{h}}{\mathrm{Time} /}$ & Ref. \\
\hline \multirow[t]{3}{*}{$\mathrm{ZrO}_{2}$} & 1000 & $15 \mathrm{HF}$ & 190 & 8 & 34 \\
\hline & 600 & $12.5 \mathrm{H}_{2} \mathrm{SO}_{4}+12.5 \mathrm{HF}$ & 240 & 4 & 28 \\
\hline & 100 & $1 \mathrm{HCl}+0.3 \mathrm{HNO}_{3}+4 \mathrm{HF}$ & 120 & 2 & 26 \\
\hline \multirow[t]{10}{*}{$\mathrm{Al}_{2} \mathrm{O}_{3}$} & - & $\mathrm{HCl}$ & 215 & 16 & 8 \\
\hline & 1000 & $10 \mathrm{HCl}$ & 240 & 6 & 31 \\
\hline & 500 & $15 \mathrm{H}_{2} \mathrm{SO}_{4}$ (with agitation) & 240 & 3 & 28 \\
\hline & 1000 & $10 \mathrm{HCl}+1 \mathrm{H}_{2} \mathrm{SO}_{4}$ & 230 & 6 & 9 \\
\hline & 700 & $10 \mathrm{HCl}+1 \mathrm{H}_{2} \mathrm{SO}_{4}$ & 230 & 6 & 10 \\
\hline & 100 & $3 \mathrm{HCl}+2 \mathrm{H}_{2} \mathrm{SO}_{4}$ & 200 & 24 & 32 \\
\hline & 1000 & $10 \mathrm{HCl}+1 \mathrm{H}_{2} \mathrm{SO}_{4}$ & 225 & 6 & 33 \\
\hline & 500 & $5 \mathrm{H}_{2} \mathrm{SO}_{4}+5 \mathrm{H}_{3} \mathrm{PO}_{4}$ (with agitation) & 240 & 4.5 & 28 \\
\hline & 500 & $15 \mathrm{HF}$ (with agitation) & 240 & 3.5 & 28 \\
\hline & 500 & $15 \mathrm{HF}+3 \mathrm{HClO}_{4}$ (with agitation) & 240 & 3.5 & 28 \\
\hline Mullite & 400 & $10 \mathrm{H}_{3} \mathrm{PO}_{4}+5 \mathrm{HF}$ & 240 & 6 & 28 \\
\hline Spinel & 300 & $12 \mathrm{H}_{2} \mathrm{SO}_{4}+1 \mathrm{HClO}_{4}$ & 240 & 10 & 28 \\
\hline \multirow[t]{5}{*}{ AlN } & 200 & $5 \mathrm{HCl}$ & 160 & 12 & 12 \\
\hline & 100 & $\mathrm{HCl}$ & 230 & 12 & 30 \\
\hline & 100 & $3 \mathrm{HNO}_{3}$ & 180 & 2 & 32 \\
\hline & 760 & $6 \mathrm{HCl}+2 \mathrm{HNO}_{3}$ & 220 & 4 & 9 \\
\hline & 760 & $9.5 \mathrm{HCl}+2 \mathrm{HNO}_{3}$ & 220 & 4 & 10 \\
\hline \multirow{2}{*}{$\mathrm{BN}$} & 30 & $4 \mathrm{H}_{2} \mathrm{SO}_{4}$ & 240 & 6 & 28 \\
\hline & 100 & $3 \mathrm{HF}+0.5 \mathrm{H}_{2} \mathrm{O}_{2}$ & 180 & 5 & 32 \\
\hline \multirow[t]{7}{*}{$\mathrm{Si}_{3} \mathrm{~N}_{4}$} & 60 & $1.5 \mathrm{HCl}+1.5 \mathrm{HF}$ & 150 & $>7$ & 35 \\
\hline & $145-660$ & $1 \mathrm{HNO}_{3}+3 \mathrm{HF}$ & 150 & $>12$ & 38 \\
\hline & 400 & $1.5 \mathrm{HNO}_{3}+2 \mathrm{HF}$ & $180-200$ & 10 & 37 \\
\hline & 250 & $3 \mathrm{HNO}_{3}+6 \mathrm{HF}$ & 200 & $6-8$ & 17 \\
\hline & 250 & $1.8 \mathrm{HNO}_{3}+5 \mathrm{HF}$ & 220 & 4 & 9 \\
\hline & 250 & $1.8 \mathrm{HNO}_{3}+5 \mathrm{HF}$ & 220 & 4 & 10 \\
\hline & 100 & $3 \mathrm{HF}+0.5 \mathrm{H}_{2} \mathrm{O}_{2}$ & 180 & 6 & 32 \\
\hline \multirow[t]{4}{*}{$\mathrm{SiC}$} & 250 & $4 \mathrm{HNO}_{3}+4 \mathrm{H}_{2} \mathrm{SO}_{4}+4 \mathrm{HF}$ & 240 & $8-20$ & 19 \\
\hline & 200 & $4 \mathrm{HNO}_{3}+3.5 \mathrm{H}_{2} \mathrm{SO}_{4}+4 \mathrm{HF}$ & 250 & 5 & 10 \\
\hline & 250 & $4 \mathrm{HNO}_{3}+4 \mathrm{H}_{2} \mathrm{SO}_{4}+4 \mathrm{HF}$ & 250 & 12 & 33 \\
\hline & 250 & $4 \mathrm{HNO}_{3}+4 \mathrm{H}_{2} \mathrm{SO}_{4}+4 \mathrm{HF}$ & 250 & 12 & 40 \\
\hline \multirow[t]{2}{*}{$\mathrm{SrTiO}_{3}$} & 300 & $25 \mathrm{HCl}$ & 240 & 2 & 28 \\
\hline & 100 & $10 \mathrm{HCl}+\mathrm{a}$ few $\mathrm{ml}$ of $\mathrm{HF}$ & 200 & 4 & 36 \\
\hline \multirow[t]{4}{*}{$\mathrm{BaTiO}_{3}$} & 50 & $15 \mathrm{HCl}$ & 150 & 16 & 22 \\
\hline & 200 & $5 \mathrm{HCl}$ & 160 & 14 & 23 \\
\hline & 200 & $5 \mathrm{HCl}$ & 160 & 16 & 13 \\
\hline & $300-500$ & $25 \mathrm{HCl}$ & 240 & 4 & 28 \\
\hline Gd-PT & 200 & $5 \mathrm{HCl}$ & 160 & 16 & 13 \\
\hline \multirow[t]{2}{*}{ PZT } & 200 & $0.4 \mathrm{H}_{2} \mathrm{SO}_{4}+2 \mathrm{HF}$ & 170 & 16 & 13 \\
\hline & 200 & $0.4 \mathrm{H}_{2} \mathrm{SO}_{4}+2 \mathrm{HF}$ & 170 & 16 & 24 \\
\hline PLZT & 200 & $0.4 \mathrm{H}_{2} \mathrm{SO}_{4}+2 \mathrm{HF}$ & 170 & 16 & 13 \\
\hline
\end{tabular}


Table 2 Summary of literature methods using acid decomposition by microwave-assisted heating at elevated pressure for the dissolution of advanced ceramic powders

\begin{tabular}{|c|c|c|c|c|c|c|c|c|}
\hline \multirow[b]{2}{*}{ Ceramic powder } & \multirow[b]{2}{*}{$\begin{array}{l}\text { Sample } \\
\text { mass/mg }\end{array}$} & \multirow[b]{2}{*}{$\begin{array}{l}\text { Acid or mixture } \\
\text { of acids } / \mathrm{ml}\end{array}$} & \multicolumn{2}{|c|}{ Stage 1} & \multicolumn{2}{|c|}{ Stage 2} & \multirow[b]{2}{*}{$\begin{array}{l}\text { Total time/ } \\
\min \end{array}$} & \multirow[b]{2}{*}{ Ref } \\
\hline & & & $\begin{array}{l}\text { Time } / \\
\min \end{array}$ & $\begin{array}{c}\text { Power/ } \\
\text { W }\end{array}$ & $\begin{array}{c}\text { Time } / \\
\min \end{array}$ & $\begin{array}{c}\text { Power/ } \\
\text { W }\end{array}$ & & \\
\hline $\mathrm{Al}_{2} \mathrm{O}_{3}(0 \% \alpha$-phase $)$ & 200 & $10 \mathrm{H}_{2} \mathrm{SO}_{4}$ & 3 & 630 & 5 & 315 & 8 & 46 \\
\hline $\mathrm{Al}_{2} \mathrm{O}_{3}(17.1 \% \alpha$-phase $)$ & 200 & $10 \mathrm{H}_{2} \mathrm{SO}_{4}$ & 3 & 630 & 120 & 315 & 123 & 46 \\
\hline $\mathrm{Al}_{2} \mathrm{O}_{3}(43.6 \% \alpha$-phase $)$ & 200 & $10 \mathrm{H}_{2} \mathrm{SO}_{4}$ & 3 & 630 & 120 & 315 & 123 & 46 \\
\hline $\mathrm{Al}_{2} \mathrm{O}_{3}(96.1 \% \alpha$-phase $)$ & 200 & $10 \mathrm{H}_{2} \mathrm{SO}_{4}$ & 3 & 630 & 240 & 315 & 243 & 46 \\
\hline $\mathrm{Al}_{2} \mathrm{O}_{3}(98.4 \% \alpha$-phase $)$ & 200 & $10 \mathrm{H}_{2} \mathrm{SO}_{4}$ & 3 & 630 & 420 & 315 & 423 & 46 \\
\hline $\mathrm{Al}_{2} \mathrm{O}_{3}(100 \% \alpha$-phase $)$ & 200 & $10 \mathrm{H}_{2} \mathrm{SO}_{4}$ & 3 & 630 & 240 & 315 & 243 & 46 \\
\hline $\mathrm{Al}_{2} \mathrm{O}_{3}(100 \% \alpha$-phase $)$ & 200 & $10 \mathrm{H}_{2} \mathrm{SO}_{4}$ & 3 & 630 & 360 & 315 & 363 & 46 \\
\hline $\mathrm{Al}_{2} \mathrm{O}_{3}$ & 100 & $3 \mathrm{HCl}+2 \mathrm{H}_{2} \mathrm{SO}_{4}$ & 5 & 250 & 15 & 500 & 20 & 32 \\
\hline AlN & 100 & $3 \mathrm{HNO}_{3}$ & 5 & 250 & 10 & 500 & 15 & 32 \\
\hline $\mathrm{BN}$ & 100 & $3 \mathrm{HF}+0.5 \mathrm{H}_{2} \mathrm{O}_{2}$ & 5 & 250 & 10 & 500 & 15 & 32 \\
\hline $\mathrm{Si}_{3} \mathrm{~N}_{4}$ & 100 & $3 \mathrm{HF}+0.5 \mathrm{H}_{2} \mathrm{O}_{2}$ & 5 & 250 & 10 & 500 & 15 & 32 \\
\hline
\end{tabular}

powders of micron and submicron particle size. Such types of powders are generally used as starting materials in the preparation of ceramics. Therefore, they cannot really be considered as ceramic materials, since ceramic materials are formed from non-metallic polycrystalline inorganic compounds having been, as a common feature, consolidated from a powder by thermal treatment at high temperatures (the so-called sintering process).

The aim of this work was to develop methodologies for the microwave-assisted dissolution of sintered bodies of a great variety of structural and electronic advanced ceramic materials for their reliable chemical analysis by ICP-AES, and to compare them with well established conventional acid decomposition and alkali fusion procedures. Another purpose was to evaluate the influence of sample solutions obtained by the different dissolution methods on the analytical figures of merit of ICP-AES.

\section{EXPERIMENTAL}

\section{Instrumentation}

\section{Microwave digestion system}

A commercially available laboratory medium pressure microwave oven (RMS-150 remote microwave-digestion system; Floyd, Lake Wyle, SC, USA) operating at a frequency of $2450 \mathrm{MHz}$ with an energy output of $0-600 \mathrm{~W}$ adjustable in $1 \%$ increments from 0 to $100 \%$ was used to perform the acid digestions. The microwave system, featuring programmable time and power (24 stage programming, 100 programme storage), consists of an oven, an extraction fan, a remote control console, a rotating turntable and 12 digestion closed vessels ( $80 \mathrm{ml}$ capacity), each of which is connected by a venting tube to a central waste container. The digestion vessels, made from perfluoroalkoxy (PFA), incorporate a double-wall design and use disposable PFA rupture discs to ensure safe operation up to a precise pressure limit of $1380 \mathrm{kPa}$.

\section{ICP atomic emission spectrometer}

Simultaneous multi-element determinations of the analytes in sample solutions were carried out with a Jobin-Yvon (Longjumeau, France) Model 70 Plus combination sequentialsimultaneous ICP atomic emission spectrometer. The instrumentation and operating conditions were described in a previous paper. ${ }^{47}$

\section{Chemicals}

\section{Reagents}

Analytical-reagent grade $\mathrm{HCl}(37 \%), \mathrm{HNO}_{3}(65 \%), \mathrm{H}_{2} \mathrm{SO}_{4}$ (95-97\%), $\mathrm{HF}(48 \%), \mathrm{H}_{2} \mathrm{O}_{2}(30 \%),\left(\mathrm{NH}_{4}\right)_{2} \mathrm{SO}_{4}, \mathrm{Na}_{2} \mathrm{CO}_{3}$,
$\mathrm{Na}_{2} \mathrm{~B}_{4} \mathrm{O}_{7}$ and $\mathrm{Li}_{2} \mathrm{~B}_{4} \mathrm{O}_{7}$ (Merck, Darmstadt, Germany) were used as reagents for dissolution procedures. De-ionized water with a resistivity $>18 \mathrm{M} \Omega \mathrm{cm}$, produced by a Milli-Q Plus pure water generating system from Millipore (Bedford, MA, USA), was used for all solutions.

\section{Standards}

For ICP-AES measurements, mono-element stock standard solutions were purchased from Merck or Spex Industries (Edison, NJ, USA), or prepared from high-purity Specpure grade oxides (Johnson Matthey Chemicals, Royston, Hertfordshire, UK). From these solutions, calibration multielement standard solutions were prepared by the serial dilution method. The different reagent blanks and the concomitant elements were also added to these standards.

\section{Samples}

All the advanced ceramic materials studied, which are specified in Table 3, were processed and sintered in the Instituto de Cerámica y Vidrio (Institute of Ceramics and Glass), Consejo Superior de Investigaciones Científicas (Superior Council of Scientific Research), Madrid, Spain.

By using mixed oxides or coprecipitated hydroxides as starting materials, green bodies were prepared by either isostatic pressing or slip casting. Subsequently, these green compacts were sintered by thermal treatment in the range 1400 $1650{ }^{\circ} \mathrm{C}$ to obtain full dense pieces (cylindrical bars, $5-10 \mathrm{~cm}$ in length and $1-2 \mathrm{~cm}$ in diameter). In some materials, hot pressing at temperatures ranging from 1500 to $1550{ }^{\circ} \mathrm{C}$ was necessary to obtain the theoretical densities.

\section{Sample Preparation}

The full dense cylindrical bars of the sintered advanced ceramics were crushed and milled to a particle size below $20-30 \mu \mathrm{m}$ in a ball milling system. After this, a particle size below $5-10 \mu \mathrm{m}$ was obtained by using an attrition milling system. In order to minimize contamination, the composition of the balls used in both ball and attrition milling systems was similar to the composition of each sample (e.g., alumina balls were used for samples with high levels of aluminium such as $\mathrm{Al}_{2} \mathrm{O}_{3}$, mullite and spinel; zirconia balls were used for samples with high levels of zirconium such as $\mathrm{m}-\mathrm{ZrO}_{2}, \mathrm{Ca}-\mathrm{PSZ}$, Mg-PSZ, Y-FSZ, Ce-TZP, Yb-TZP, Y-TZP/Ce, PZT and PLZT). 
Table 3 Sintered advanced ceramic materials used in the present work

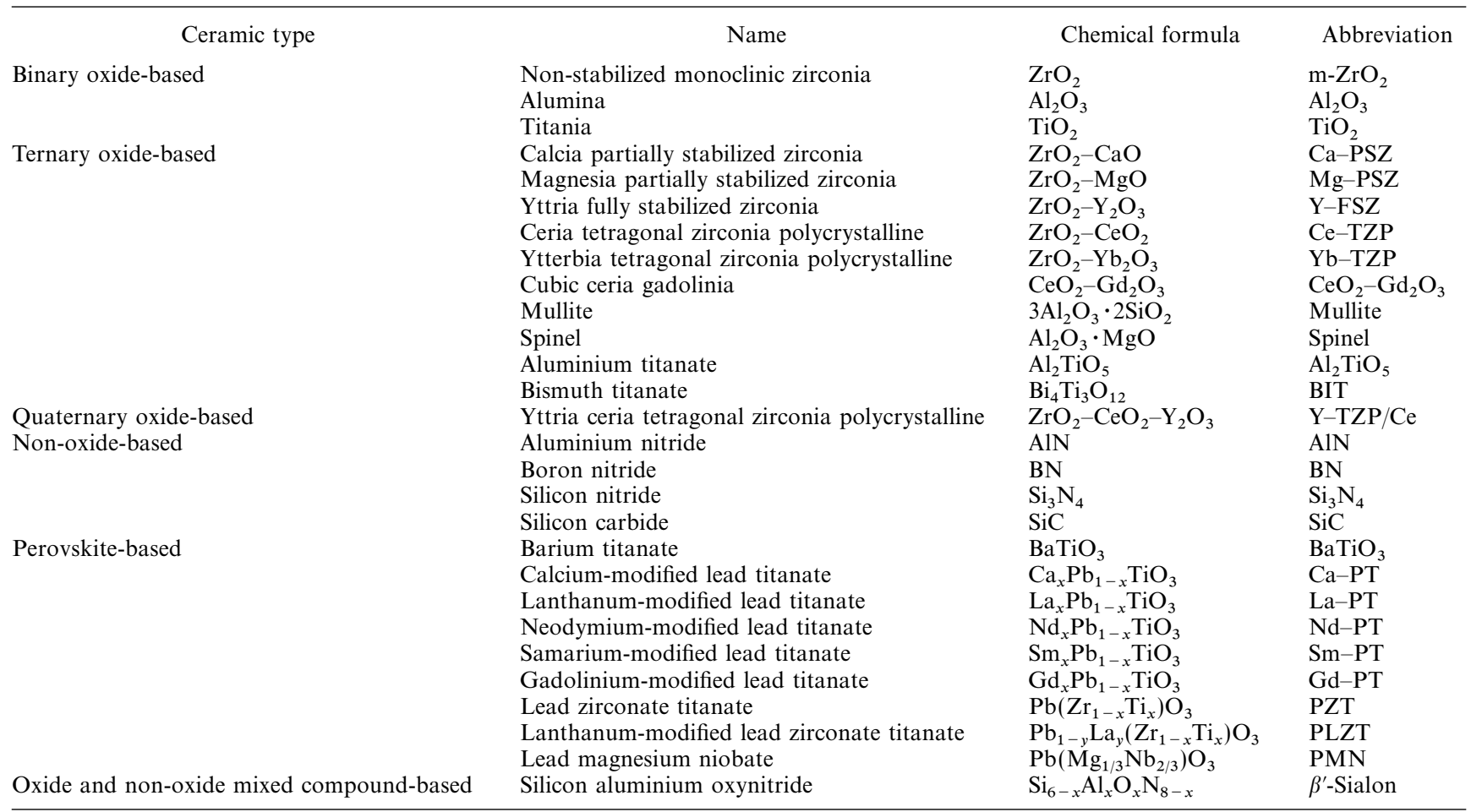

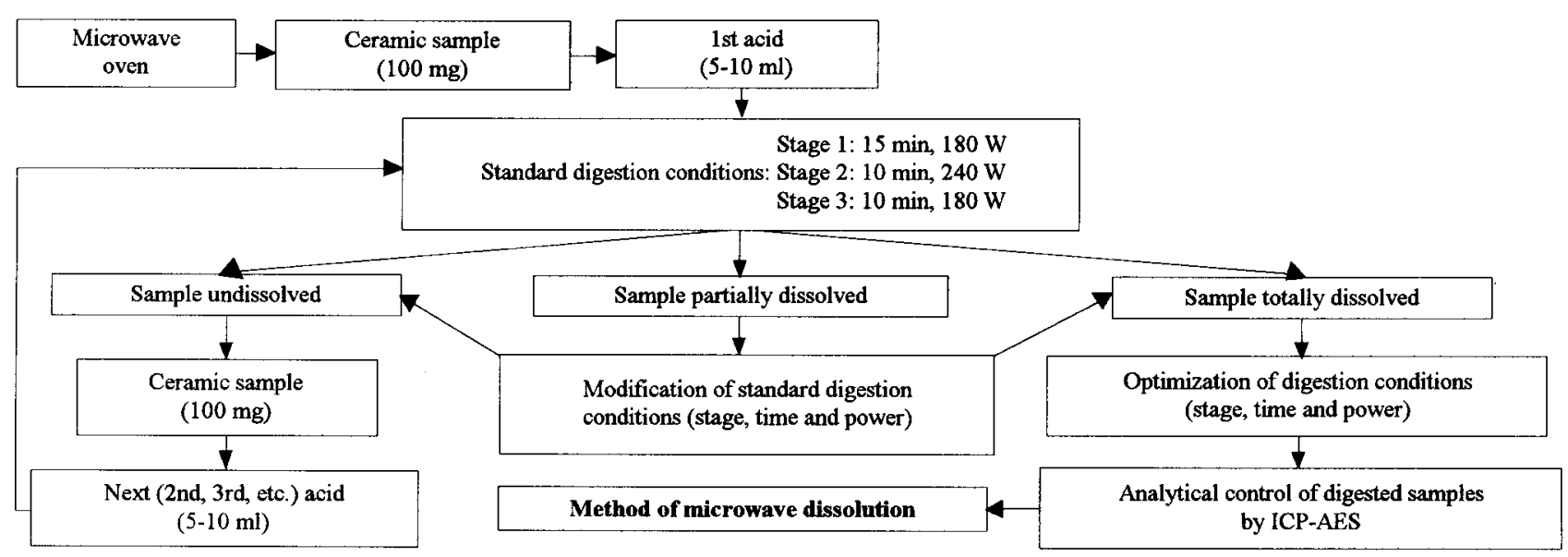

Fig. 1 Schematic diagram of the procedure for the microwave-assisted dissolution of the advanced ceramic materials.

\section{Procedures}

Sample dissolution by microwave-assisted digestion

A multi-step procedure, outlined in Fig. 1, was used. For each of the advanced ceramic materials, the acid or mixture of acids were used following the order given in Table 4, until full dissolution was obtained. About $100 \mathrm{mg}$ of sample and 5-10 ml of the first acid in Table 4, $\mathrm{HCl}$, were added, in duplicate, to the digestion vessels and were treated with the microwave standard digestion conditions indicated in Fig. 1 (stage 1, $15 \mathrm{~min}$ at $180 \mathrm{~W}$; stage $2,10 \mathrm{~min}$ at $240 \mathrm{~W}$; and stage $3,10 \mathrm{~min}$ at $180 \mathrm{~W}$ ). Three situations could arise. (i) If the sample was not dissolved, that means that the powder remains (with the same aspect as it had before the treatment was applied); in this case, the sample was tested with the second acid in Table 4 $\left(\mathrm{HNO}_{3}\right)$. If the sample remained undissolvable, it was assayed with the next acid $\left(\mathrm{H}_{2} \mathrm{SO}_{4}\right)$, and so on until it was dissolved. (ii) If the sample was partially dissolved or at least was attacked, that means that the powder has a different aspect to that of the initial powder; in this case, the standard digestion conditions were modified with respect to number of stages,
Table 4 Acids and mixtures of acids tested for the microwave-assisted dissolution of ceramic materials

\begin{tabular}{|c|c|}
\hline Order & Acid or mixture of acids \\
\hline $1 \mathrm{st}$ & $\mathrm{HCl}$ \\
\hline 2nd & $\mathrm{HNO}_{3}$ \\
\hline $3 \mathrm{rd}$ & $\mathrm{H}_{2} \mathrm{SO}_{4}$ \\
\hline 4th & $\mathrm{HCl}+\mathrm{HNO}_{3}(3+1 \mathrm{v} / \mathrm{v} ;$ aqua regia $)$ \\
\hline 5 th & $\left(\mathrm{NH}_{4}\right)_{2} \mathrm{SO}_{4} 20 \% \mathrm{~m} / \mathrm{v}$ in $\mathrm{H}_{2} \mathrm{SO}_{4}$ \\
\hline 6th & $\mathrm{HCl}+\mathrm{HF}$ \\
\hline 7 th & $\mathrm{HNO}_{3}+\mathrm{HF}$ \\
\hline 8 th & $\mathrm{H}_{2} \mathrm{SO}_{4}+\mathrm{HF}$ \\
\hline 9 th & $\mathrm{HCl}+\mathrm{HNO}_{3}(3+1 \mathrm{v} / \mathrm{v})+\mathrm{HF}$ \\
\hline 10th & $\left(\mathrm{NH}_{4}\right)_{2} \mathrm{SO}_{4} 20 \% \mathrm{~m} / \mathrm{v}$ in $\mathrm{H}_{2} \mathrm{SO}_{4}+\mathrm{HF}$ \\
\hline 11 th & $\mathrm{HNO}_{3}+\mathrm{H}_{2} \mathrm{SO}_{4}+\mathrm{HF}$ \\
\hline 12 th & $\mathrm{HCl}+\mathrm{H}_{2} \mathrm{O}_{2}$ \\
\hline 13 th & $\mathrm{HNO}_{3}+\mathrm{H}_{2} \mathrm{O}_{2}$ \\
\hline 14 th & $\mathrm{H}_{2} \mathrm{SO}_{4}+\mathrm{H}_{2} \mathrm{O}_{2}$ \\
\hline 15 th & $\mathrm{HF}+\mathrm{H}_{2} \mathrm{O}_{2}$ \\
\hline
\end{tabular}


digestion time and/or microwave oven power, until the total dissolution of the sample was achieved. If total dissolution was not achieved, the same steps as the previous case must be applied. When total dissolution had been achieved, the next stage was applied. (iii) When the sample was completely dissolved, at least apparently, which means that a transparent solution appeared, the microwave digestion conditions (amounts of acids, number of stages, time and power of each stage) were optimized, checking accurately the amount of sample dissolved by means of the ICP-AES determination of the macro-constituents of the ceramic material. In this way, an improved method for the microwave-assisted dissolution of the ceramic material was created. The dissolved sample was completely transferred into a $100 \mathrm{ml}$ calibrated flask and diluted to volume with water.

\section{Sample dissolution by fusion with $\mathrm{Li}_{2} \mathrm{~B}_{4} \mathrm{O}_{7}$ in a graphite crucible}

The sample $(0.2000 \mathrm{~g})$ was mixed with $2.00 \mathrm{~g}$ of $\mathrm{Li}_{2} \mathrm{~B}_{4} \mathrm{O}_{7}$ in a porcelain crucible and then quantitatively transferred into a graphite crucible. The mixture was fused in a muffle furnace at $1100{ }^{\circ} \mathrm{C}$ for $20 \mathrm{~min}$. The melt was then carefully and quickly poured into a $400 \mathrm{ml}$ glass beaker containing $100 \mathrm{ml}$ of cold $\mathrm{HNO}_{3}(1+24 \mathrm{v} / \mathrm{v})$. The contents were stirred with a PTFEcovered magnetic bar on top of a magnetic plate until the melt dissolved. The solution was completely transferred into a $200 \mathrm{ml}$ calibrated flask and diluted to volume with $\mathrm{HNO}_{3}$ $(1+24 \mathrm{v} / \mathrm{v})$.

Sample dissolution by fusion with $\mathrm{Na}_{2} \mathrm{CO}_{3}+\mathrm{Na}_{2} \mathrm{~B}_{4} \mathrm{O}_{7}$ in a platinum crucible

The sample $(0.2000 \mathrm{~g})$ was mixed with $2.00 \mathrm{~g}$ of $\mathrm{Na}_{2} \mathrm{CO}_{3}+\mathrm{Na}_{2} \mathrm{~B}_{4} \mathrm{O}_{7}(53.7+46.3 \% \mathrm{~m} / \mathrm{m})$ in a platinum crucible and fused by heating on a Mekker burner for $30 \mathrm{~min}$. The crucible was carefully introduced into a $250 \mathrm{ml}$ glass beaker containing $100 \mathrm{ml}$ of hot $\mathrm{HCl}(1+9 \mathrm{v} / \mathrm{v})$ and gently heated until the fused sample was dissolved. The solution was completely transferred into a $200 \mathrm{ml}$ calibrated flask and diluted to volume with $\mathrm{HCl}(1+9 \mathrm{v} / \mathrm{v})$.

\section{Determination of impurities in attack reagents by ICP-AES}

Impurities of $\mathrm{Ca}, \mathrm{Fe}, \mathrm{Mg}$, $\mathrm{Si}$ and $\mathrm{Sr}$ were determined by ICPAES in the water and in the following acids used in the microwave-assisted dissolution of the sintered advanced ceramics: $5 \% \mathrm{HCl}, 5 \% \mathrm{HNO}_{3}, 5 \% \mathrm{H}_{2} \mathrm{SO}_{4}, 1 \%\left(\mathrm{NH}_{4}\right)_{2} \mathrm{SO}_{4}$ and $5 \% \mathrm{H}_{2} \mathrm{SO}_{4}+1 \%\left(\mathrm{NH}_{4}\right)_{2} \mathrm{SO}_{4}$. Also, the same elements were determined in the attack reagents (acids and fluxes) employed in the dissolution of the samples by fusion in a graphite crucible $\left(4 \% \mathrm{HNO}_{3}\right.$ and $\left.4 \% \mathrm{HNO}_{3}+1 \% \mathrm{Li}_{2} \mathrm{~B}_{4} \mathrm{O}_{7}\right)$ and by fusion in a platinum crucible $\left(10 \% \mathrm{HCl}, 0.54 \% \mathrm{Na}_{2} \mathrm{CO}_{3}\right.$, $\begin{array}{lllll}0.46 \% & \mathrm{Na}_{2} \mathrm{~B}_{4} \mathrm{O}_{7} \text { and } 10 \% \mathrm{HCl}+0.54 \% \quad \mathrm{Na}_{2} \mathrm{CO}_{3}+0.46 \%\end{array}$ $\left.\mathrm{Na}_{2} \mathrm{~B}_{4} \mathrm{O}_{7}\right)$. The measurements were performed on the $393.366 \mathrm{~nm}$ line of $\mathrm{Ca}$ II, the $239.562 \mathrm{~nm}$ line of Fe II, the $279.553 \mathrm{~nm}$ line of $\mathrm{Mg}$ II, the $251.611 \mathrm{~nm}$ line of Si I and the $407.771 \mathrm{~nm}$ line of Sr II.

\section{Determination of the detection limits of minor elements by} ICP-AES

The detection limit was defined as the concentration which gave a net signal equal to three times the standard deviation of the background level $(3 \sigma)$. The determination of the detection limits for the most sensitive lines ${ }^{48}$ of 16 elements (Table 5) was performed in solutions containing three different reagent blanks: (i) the blank corresponding to the hydrochloric acid microwave-assisted dissolution $(5 \% \mathrm{HCl})$; (ii) the blank corresponding to the alkali fusion in a graphite crucible $(4 \%$
Table 5 Elements and emission lines used for the determination of detection limits

\begin{tabular}{lclc}
\hline Element & Emission line $/ \mathrm{nm}$ & Element & Emission line $/ \mathrm{nm}$ \\
Ca II & 393.366 & $\mathrm{Mn} \mathrm{II}$ & 257.610 \\
Ce II & 413.765 & $\mathrm{Na}$ I & 589.592 \\
$\mathrm{Cu}$ I & 324.754 & $\mathrm{Nd}$ II & 415.608 \\
Fe II & 239.562 & $\mathrm{P} \mathrm{I}$ & 213.618 \\
Gd II & 336.223 & Si I & 251.611 \\
K I & 766.490 & Sm II & 442.434 \\
La II & 408.672 & Sr II & 407.771 \\
Mg II & 279.553 & Zr II & 343.823 \\
\hline
\end{tabular}

$\mathrm{HNO}_{3}+1 \% \mathrm{Li}_{2} \mathrm{~B}_{4} \mathrm{O}_{7}$ ); and (iii) the blank corresponding to the alkali fusion in a platinum crucible $(10 \% \mathrm{HCl}+0.54 \%$ $\left.\mathrm{Na}_{2} \mathrm{CO}_{3}+0.46 \% \quad \mathrm{Na}_{2} \mathrm{~B}_{4} \mathrm{O}_{7}\right)$. The influence of the major elements of each advanced ceramic material was not considered.

\section{Chemical analysis of advanced ceramic materials}

The chemical analysis of the advanced ceramic materials was carried out in triplicate for each dissolution method (acid microwave heating, alkali fusion with $\mathrm{Li}_{2} \mathrm{~B}_{4} \mathrm{O}_{7}$ in a graphite crucible and alkali fusion with $\mathrm{Na}_{2} \mathrm{CO}_{3}+\mathrm{Na}_{2} \mathrm{~B}_{4} \mathrm{O}_{7}$ in a platinum crucible). The determination of the macro-constituents was performed on the 20-fold diluted sample solution. However, the determination of impurities was performed directly on the sample solution.

\section{RESULTS AND DISCUSSION}

The acids in Table 4 are those which have been most often used to dissolve advanced ceramic materials (Table 1). The acids are listed in order of increasing strength. In first place appear the acids alone, in second place the mixtures of these acids and in third place these acids and their mixtures with $\mathrm{HF}$. In last place are also included powerful oxidizing mixtures (the previous acids in the presence of $\mathrm{H}_{2} \mathrm{O}_{2}$ ) which are effective in achieving the dissolution of several non-oxide-based ceramics $\left(\mathrm{BN}\right.$ and $\left.\mathrm{Si}_{3} \mathrm{~N}_{4}\right)$, as is inferred of Table 1. Since temperature cannot be measured in our microwave digestion system, $\mathrm{HClO}_{4}$ was not used because a temperature can easily be exceeded without reaching the maximum pressure. Nevertheless, we included the mixture of $\left(\mathrm{NH}_{4}\right)_{2} \mathrm{SO}_{4}+\mathrm{H}_{2} \mathrm{SO}_{4}$, which although it has not been used previously in attacks in a PTFE bomb, it has been employed with success in attacks in a beaker to dissolve $\mathrm{ZrO}_{2},{ }^{11,26} \mathrm{Y}-\mathrm{TZP},{ }^{12} \mathrm{Gd}-\mathrm{PT},{ }^{13} \mathrm{PZT}^{13,14}$ and PLZT,${ }^{13}$ and also in attacks in a platinum dish to dissolve $\mathrm{Ca}-\mathrm{PSZ}$ and $\mathrm{Y}-\mathrm{TZP} / \mathrm{Ce}^{13}$

As can be seen when Tables 1, 2 and 3 are compared, only 12 of the 28 advanced ceramic materials tested in this work had been studied using acid dissolution in PTFE bomb, and only four of these 12 had been studied using microwaveassisted dissolution. Moreover, the samples studied in these earlier papers were not in fact ceramic materials, but commercial powders, generally of submicron particle size, which are used as raw materials for advanced ceramics manufacture. Any ceramic material is sintered by a high temperature treatment (1300- $1700^{\circ} \mathrm{C}$ or even higher), which is responsible for the formation of the ceramic material, which is a polycrystalline inorganic solid and which therefore always has a higher refractoriness and chemical inertness than the initial powders, and whose dissolution requires stronger conditions.

The results obtained after the attack of the 28 advanced ceramic materials in the microwave oven, with the acids in Table 4 and following the procedure in Fig. 1, are given in Table 6 .

For the materials with high levels of zirconium, the mixture 


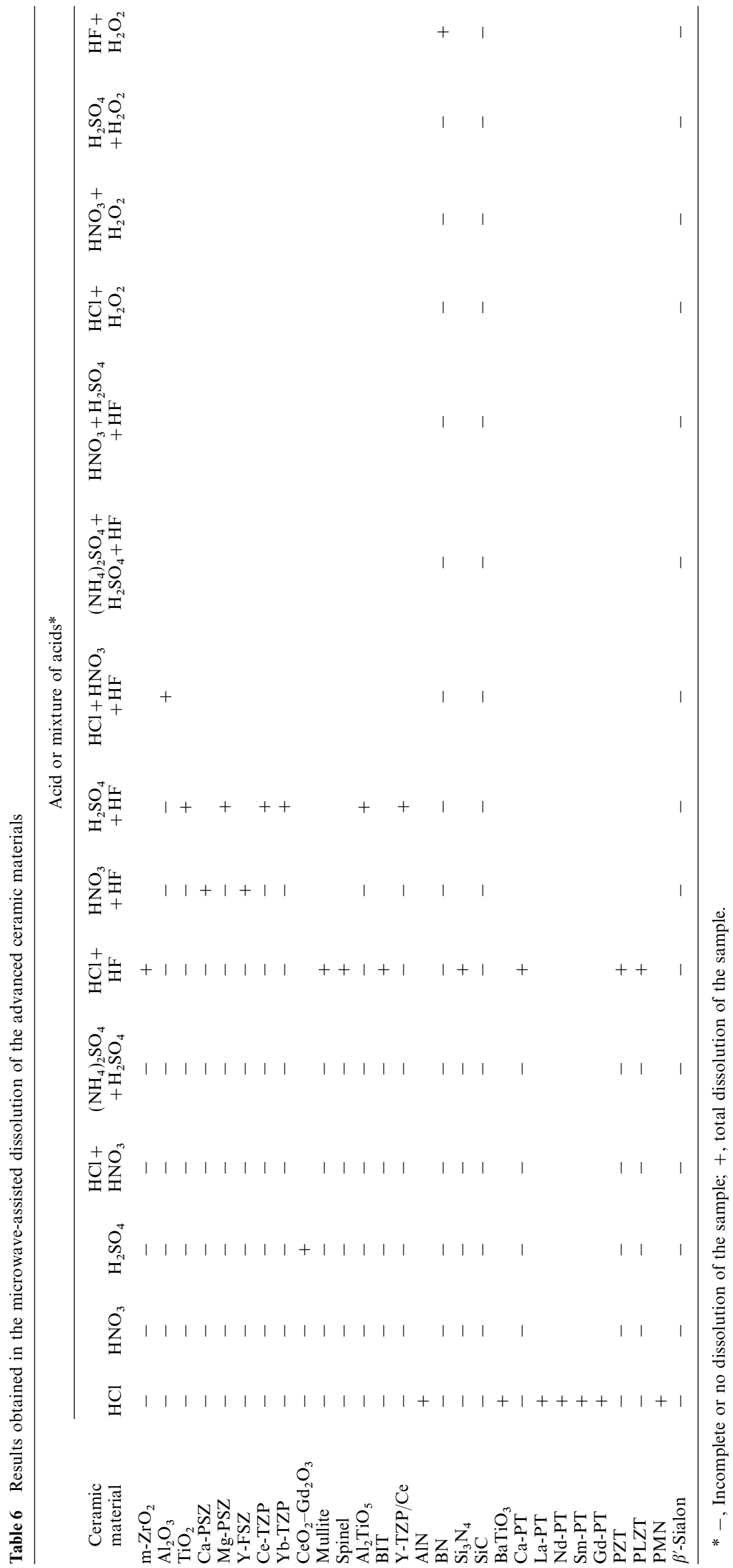


of $\left(\mathrm{NH}_{4}\right)_{2} \mathrm{SO}_{4}+\mathrm{H}_{2} \mathrm{SO}_{4}$, which has been used in open vessels (a beaker or platinum dish) with success in the literature, did not dissolved any of the sample. In all cases, the presence of $\mathrm{HF}$ was required. For the materials which contain lower levels of zirconium, such as PZT and PLZT, and also for the nonstabilized monoclinic zirconia $\left(\mathrm{m}-\mathrm{ZrO}_{2}\right)$, the use of $\mathrm{HCl}$ with $\mathrm{HF}$ was sufficient to dissolve these samples. For the partially or fully stabilized zirconias, which are more refractory ceramics, the presence of stronger acids $\left(\mathrm{HNO}_{3}\right.$ or $\left.\mathrm{H}_{2} \mathrm{SO}_{4}\right)$ was required. It can be seen in Table 1 that the dissolution of such materials in PTFE bombs also required the presence of HF.

The materials with high levels of aluminium $\left(\mathrm{Al}_{2} \mathrm{O}_{3}\right.$, mullite and spinel), high levels of titanium $\left(\mathrm{TiO}_{2}\right.$ and $\left.\mathrm{BIT}\right)$ or high levels of aluminium and titanium $\left(\mathrm{Al}_{2} \mathrm{TiO}_{5}\right)$ also required the presence of $\mathrm{HF}$, with $\mathrm{HCl}$ for materials with lower levels of these elements (mullite, spinel and BIT) or with $\mathrm{H}_{2} \mathrm{SO}_{4}$ or aqua regia for materials with high levels of those elements $\left(\mathrm{Al}_{2} \mathrm{O}_{3}, \mathrm{TiO}_{2}\right.$ and $\left.\mathrm{Al}_{2} \mathrm{TiO}_{5}\right)$. In the dissolution procedures in PTFE bombs (Table 1), some workers also required the presence of $\mathrm{HF}$ to dissolve $\mathrm{Al}_{2} \mathrm{O}_{3}$ and mullite; however, other workers achieved the dissolution of these materials with $\mathrm{HCl}$, $\mathrm{H}_{2} \mathrm{SO}_{4}$ or mixtures of $\mathrm{HCl}+\mathrm{H}_{2} \mathrm{SO}_{4}$ or $\mathrm{H}_{2} \mathrm{SO}_{4}+\mathrm{HClO}_{4}$, by means of elevated temperatures $\left(>200^{\circ} \mathrm{C}\right.$ ) and long times (even $24 \mathrm{~h}$ ). For microwave-assisted dissolution, Tatár et $a .^{46}$ used only $\mathrm{H}_{2} \mathrm{SO}_{4}(1+1)$ to dissolve powders of alumina with different levels of the $\alpha-\mathrm{Al}_{2} \mathrm{O}_{3}$ phase, which is the crystalline phase of high temperature and with the highest chemical inertia. For the powders with high levels $(>90 \%)$ of $\alpha-\mathrm{Al}_{2} \mathrm{O}_{3}$ dissolution times between 4 and $7 \mathrm{~h}$ are required. Matusiewicz ${ }^{32}$ used $\mathrm{HCl}$ and $\mathrm{H}_{2} \mathrm{SO}_{4}$ to dissolve in $20 \mathrm{~min}$ a commercial powder of $\mathrm{Al}_{2} \mathrm{O}_{3}$.

To our knowledge, no procedure for dissolving $\mathrm{CeO}_{2}-\mathrm{Gd}_{2} \mathrm{O}_{3}$ ceramics has been described previously. According to laboratory experience, alkali fusions were not fully efficient. However, complete dissolution was easily achieved by the microwave treatment with $\mathrm{H}_{2} \mathrm{SO}_{4}$.

$\mathrm{PMN}$, for which also no dissolution procedure has been described previously, was dissolved with $\mathrm{HCl}$ alone. $\mathrm{BaTiO}_{3}$ was also dissolved by $\mathrm{HCl}$ treatment, which is the same acid used by others ${ }^{13,22,23,28}$ for dissolution in PTFE bombs (Table 1).

The use of $\mathrm{HCl}$ alone was sufficient to dissolve the rare earth element-modified lead titanates (La-PT, Nd-PT, Sm-PT and Gd-PT); however, Ca-PT required the additional use of $\mathrm{HF}$.

The non-oxidic ceramics have shown varied behaviour. AlN has been dissolved with $\mathrm{HCl}$ alone, while other workers used $\mathrm{HNO}_{3}{ }^{32}$ for microwave-assisted dissolution (Table 2) and $\mathrm{HCl}^{12,30} \mathrm{HNO}_{3}{ }^{32}$ or aqua regia ${ }^{9,10}$ for acid decomposition in a PTFE bomb (Table 1). BN has been dissolved with HF and $\mathrm{H}_{2} \mathrm{O}_{2}$, which are the same reagents as used by other workers to dissolve this material by acid decomposition in a PTFE bomb $^{32}$ (Table 1) and by microwave-assisted digestion ${ }^{32}$ (Table 2). The dissolution of $\mathrm{Si}_{3} \mathrm{~N}_{4}$ has been carried out with $\mathrm{HCl}+\mathrm{HF}$, which is the same acid mixture as used by Parker et al. ${ }^{35}$ for acid decomposition in a PTFE bomb, whereas other workers required the use of $\mathrm{HNO}_{3}+\mathrm{HF}^{9,10,17,37,38}$ for acid decomposition in PTFE bomb or $\mathrm{HF}+\mathrm{H}_{2} \mathrm{O}_{2}{ }^{32}$ for acid decomposition in a PTFE bomb or by microwave-assisted digestion.

$\mathrm{SiC}$ and $\beta^{\prime}$-sialon are the only materials that could not be dissolved by means of any acid or mixture of acids tested. Also, no method for the microwave-assisted dissolution of these materials could be found in the literature. Only one method, used by Broekaert and co-workers in several studies, ${ }^{10,19,33,40}$ could be found for the acid decomposition of $\mathrm{SiC}$ powders with $\mathrm{HNO}_{3}+\mathrm{H}_{2} \mathrm{SO}_{4}+\mathrm{HF}$ in a PTFE bomb (Table 1). In fact, this is the main disadvantage of microwaveassisted dissolution, and in general of all acid decomposition procedures, i.e., not all the sintered advanced ceramics can be completely dissolved. In contrast, it can be stated, from our experience in the Chemical Analysis Department of the Institute of Ceramics and Glass, Madrid, Spain, that all sintered advanced ceramics can be dissolved by any fusion procedure, by using different types of crucibles, such as platinum, graphite, zirconium or nickel, and different types of fluxes, such as caustic alkalis $(\mathrm{NaOH}, \mathrm{KOH}), \mathrm{Na}_{2} \mathrm{O}_{2}$, alkaline carbonates $\left(\mathrm{Na}_{2} \mathrm{CO}_{3}, \mathrm{~K}_{2} \mathrm{CO}_{3}\right)$, boron compounds $\left[\mathrm{Na}_{2} \mathrm{~B}_{4} \mathrm{O}_{7}\right.$, $\left.\mathrm{Li}_{2} \mathrm{~B}_{4} \mathrm{O}_{7}, \mathrm{LiBO}_{2}, \mathrm{Sr}\left(\mathrm{BO}_{2}\right)_{2}\right], \mathrm{Na}_{2} \mathrm{CO}_{3}+$ a boron compound $\left(\mathrm{B}_{2} \mathrm{O}_{3}, \mathrm{H}_{3} \mathrm{BO}_{3}, \mathrm{NaBO}_{2}, \mathrm{Na}_{2} \mathrm{~B}_{4} \mathrm{O}_{7}\right), \mathrm{Na}_{2} \mathrm{CO}_{3}+$ a refractory oxide (usually $\mathrm{ZnO}$ ), $\mathrm{Na}_{2} \mathrm{CO}_{3}+\mathrm{S}, \mathrm{Na}_{2} \mathrm{CO}_{3}+\mathrm{NaNO}_{3}, \mathrm{KHSO}_{4}$, alkali metal or ammonium fluorides $\left(\mathrm{NH}_{4} \mathrm{HF}_{2}, \mathrm{KHF}_{2}, \mathrm{NaF}\right.$, $\left.\mathrm{KF}, \mathrm{Na}_{2} \mathrm{SiF}_{6}, \mathrm{NaBF}_{4}, \mathrm{H}_{3} \mathrm{BO}_{3}+\mathrm{NaF}, \mathrm{H}_{3} \mathrm{BO}_{3}+\mathrm{LiF}\right)$ or $\mathrm{CaCO}_{3}+\mathrm{NH}_{4} \mathrm{Cl}$. In this way, $\mathrm{SiC}$ can be dissolved by fusion with $\mathrm{Na}_{2} \mathrm{CO}_{3}$ in a platinum crucible and dissolution of the fused sample with hot water, and $\beta^{\prime}$-sialon can be dissolved by fusion with $\mathrm{Na}_{2} \mathrm{CO}_{3}+\mathrm{Na}_{2} \mathrm{~B}_{4} \mathrm{O}_{7}$ in a platinum crucible and dissolution of the fused sample with hot dilute $\mathrm{HCl}$.

Table 7 shows 11 optimized methods which have been developed and which allow the microwave-assisted dissolution of all the advanced ceramic materials tested, except $\mathrm{SiC}$ and $\beta^{\prime}$-sialon. All of them have a maximum of three stages, although several are developed in only two stages, and method 2 has only one stage. The microwave oven power used goes from $20 \%(120 \mathrm{~W})$ to $60 \%(360 \mathrm{~W})$, which is therefore much less than the maximum power of the equipment $(600 \mathrm{~W})$. The method times extend from 15 to $35 \mathrm{~min}$, much shorter than that required to dissolve this type of material by acid decomposition in a PTFE bomb, as shown in Table 1.

As an example, Fig. 2 shows the results obtained in the analytical control by ICP-AES of $\mathrm{BaTiO}_{3}$ attacked with $5 \mathrm{ml}$ of $\mathrm{HCl}$ following microwave method 11. Solubilization of more than the $90 \%$ of the sample is achieved in the first $10-15 \mathrm{~min}$, that is, in stage 1 , and complete dissolution is achieved by increasing of the microwave oven power and by increasing the digestion time to $35 \mathrm{~min}$. It can also be seen that the two elements are dissolved with different speeds. The element that requires more time for dissolution is $\mathrm{Ti}$, because it has a higher refractoriness than $\mathrm{Ba}$. This analytical control was carried out for all the materials, and all of them had a similar behaviour to $\mathrm{BaTiO}_{3}$, that is, most of the sample is solubilized in the first few minutes, usually at different speeds for each of the macro-constituents (the more refractory the element, the more slowly it is dissolved) and total dissolution is achieved by increasing of the microwave oven power and the digestion time.

Table 8 shows the complete procedures, that is, the acids or acid mixtures and the microwave method, which allow the dissolution of all the advanced ceramic materials studied (except $\mathrm{SiC}$ and $\beta^{\prime}$-sialon, as mentioned previously). The most significant case is $\mathrm{Al}_{2} \mathrm{O}_{3}$, which required three consecutive methods (methods 2, 3 and 1), each of them with different acids, to achieve its dissolution, because it is one of the most refractory ceramic materials that exists.

Fig. 3 shows the results obtained in the determination of some impurities in the attack reagents most frequently used in microwave-assisted dissolution, and in the attack reagents used in alkali fusions in graphite and platinum crucibles. The results corresponding to $\mathrm{Li}_{2} \mathrm{~B}_{4} \mathrm{O}_{7}$ alone (without $\mathrm{HNO}_{3}$ ) are not included because this melting agent is not completely soluble in water. As can be seen, the level of impurities in the reagents used in the alkali fusions is higher than the amount of the impurities in the acids used in the microwave-assisted dissolution, in a ratio of 5-15 times for $\mathrm{Ca}, \mathrm{Fe}, \mathrm{Si}$ and $\mathrm{Sr}$ and nearly 100 times for $\mathrm{Mg}$. This higher purity of the reagent blank solutions implies another great advantage of microwaveassisted dissolution over alkali fusions for the determination of elements at low concentrations in advanced ceramic materials. In addition, it must be remarked that, for all the attack 
Table 7 Methods developed for the microwave-assisted dissolution of the advanced ceramic materials

\begin{tabular}{|c|c|c|c|c|c|c|c|}
\hline \multirow[b]{2}{*}{$\begin{array}{l}\text { Microwave } \\
\text { method }\end{array}$} & \multicolumn{2}{|c|}{ Stage 1} & \multicolumn{2}{|c|}{ Stage 2} & \multicolumn{2}{|c|}{ Stage 3} & \multirow[b]{2}{*}{$\begin{array}{l}\text { Total time } / \\
\min \end{array}$} \\
\hline & $\begin{array}{l}\text { Time/ } \\
\min \end{array}$ & $\begin{array}{c}\text { Power/ } \\
\text { W }\end{array}$ & $\begin{array}{l}\text { Time/ } \\
\min \end{array}$ & $\begin{array}{c}\text { Power/ } \\
\text { W }\end{array}$ & $\begin{array}{l}\text { Time/ } \\
\min \end{array}$ & $\begin{array}{c}\text { Power/ } \\
\text { W }\end{array}$ & \\
\hline 1 & 15 & 180 & 10 & 240 & 10 & 180 & 35 \\
\hline 2 & 15 & 120 & - & - & - & - & 15 \\
\hline 3 & 15 & 150 & 10 & 180 & - & - & 25 \\
\hline 4 & 15 & 180 & 5 & 240 & 10 & 180 & 30 \\
\hline 5 & 15 & 180 & 5 & 240 & - & - & 20 \\
\hline 6 & 10 & 120 & 5 & 180 & 5 & 120 & 20 \\
\hline 7 & 15 & 180 & 5 & 300 & - & - & 20 \\
\hline 8 & 10 & 180 & 5 & 240 & 5 & 120 & 20 \\
\hline 9 & 15 & 240 & 10 & 300 & - & - & 25 \\
\hline 10 & 10 & 240 & 10 & 300 & 5 & 360 & 25 \\
\hline 11 & 15 & 180 & 10 & 300 & 10 & 180 & 35 \\
\hline
\end{tabular}

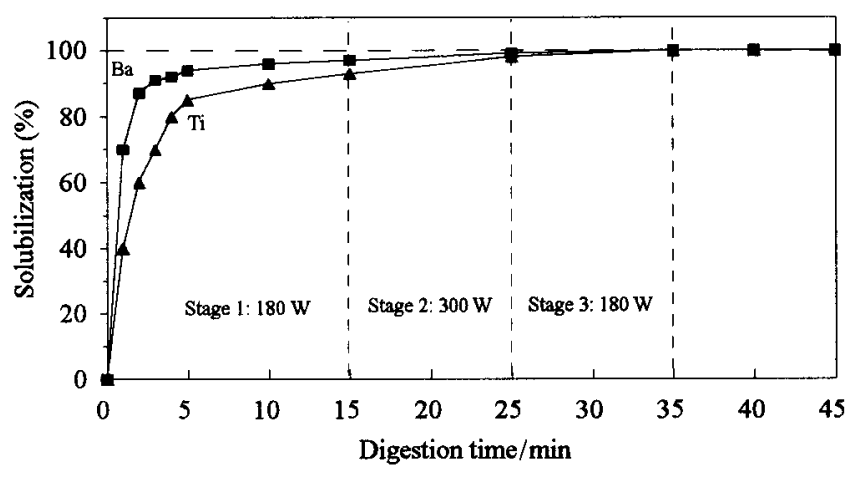

Fig. 2 Solubilization of $\mathrm{BaTiO}_{3}$ ceramic material by microwaveassisted heating with $5 \mathrm{ml}$ of $\mathrm{HCl}$ as a function of digestion time.

Table 8 Procedures for microwave-assisted dissolution of the advanced ceramic materials

\begin{tabular}{|c|c|c|}
\hline $\begin{array}{l}\text { Ceramic material } \\
\qquad(100 \mathrm{mg})\end{array}$ & Acid or mixture of acids & $\begin{array}{l}\text { Microwave } \\
\text { method }\end{array}$ \\
\hline $\mathrm{m}-\mathrm{ZrO}_{2}$ & $5 \mathrm{ml} \mathrm{HCl}+0.5 \mathrm{ml} \mathrm{HF}$ & 1 \\
\hline $\mathrm{Al}_{2} \mathrm{O}_{3}$ & $1.5 \mathrm{ml} \mathrm{HF}$ & 2 \\
\hline & $+3 \mathrm{ml} \mathrm{HCl}+1 \mathrm{ml} \mathrm{HNO}_{3}$ & 3 \\
\hline & $+2 \mathrm{ml} \mathrm{HCl}$ & 1 \\
\hline $\mathrm{TiO}_{2}$ & $5 \mathrm{ml} \mathrm{H}_{2} \mathrm{SO}_{4}+1 \mathrm{ml} \mathrm{HF}$ & 4 \\
\hline Ca-PSZ & $5 \mathrm{ml} \mathrm{HNO}+3+0.5 \mathrm{ml} \mathrm{HF}$ & 5 \\
\hline Mg-PSZ & $5 \mathrm{ml} \mathrm{H}_{2} \mathrm{SO}_{4}+0.5 \mathrm{ml} \mathrm{HF}$ & 6 \\
\hline Y-FSZ & $6 \mathrm{ml} \mathrm{HNO}_{3}+1 \mathrm{ml} \mathrm{HF}$ & 7 \\
\hline Ce-TZP & $5 \mathrm{ml} \mathrm{H}_{2} \mathrm{SO}_{4}+0.5 \mathrm{ml} \mathrm{HF}$ & 5 \\
\hline $\mathrm{Yb}-\mathrm{TZP}$ & $5 \mathrm{ml} \mathrm{H}_{2} \mathrm{SO}_{4}+0.5 \mathrm{ml} \mathrm{HF}$ & 5 \\
\hline $\mathrm{CeO}_{2}-\mathrm{Gd}_{2} \mathrm{O}_{3}$ & $5 \mathrm{ml} \mathrm{H}_{2} \mathrm{SO}_{4}$ & 8 \\
\hline Mullite & $6 \mathrm{ml} \mathrm{HCl}+1 \mathrm{ml} \mathrm{HF}$ & 1 \\
\hline Spinel & $6 \mathrm{ml} \mathrm{HCl}+1 \mathrm{ml} \mathrm{HF}$ & 1 \\
\hline $\mathrm{Al}_{2} \mathrm{TiO}_{5}$ & $5 \mathrm{ml} \mathrm{H}_{2} \mathrm{SO}_{4}+0.5 \mathrm{ml} \mathrm{HF}$ & 5 \\
\hline BIT & $5 \mathrm{ml} \mathrm{HCl}+0.5 \mathrm{ml} \mathrm{HF}$ & 1 \\
\hline $\mathrm{Y}-\mathrm{TZP} / \mathrm{Ce}$ & $5 \mathrm{ml} \mathrm{H}_{2} \mathrm{SO}_{4}+0.5 \mathrm{ml} \mathrm{HF}$ & 5 \\
\hline $\mathrm{AlN}$ & $5 \mathrm{ml} \mathrm{HCl}$ & 5 \\
\hline $\mathrm{BN}$ & $3 \mathrm{ml} \mathrm{HF}+0.5 \mathrm{ml} \mathrm{H}_{2} \mathrm{O}_{2}$ & 9 \\
\hline $\mathrm{Si}_{3} \mathrm{~N}_{4}$ & $3 \mathrm{ml} \mathrm{HCl}+3 \mathrm{ml} \mathrm{HF}$ & 10 \\
\hline $\mathrm{SiC}$ & - & - \\
\hline $\mathrm{BaTiO}_{3}$ & $5 \mathrm{ml} \mathrm{HCl}$ & 11 \\
\hline $\mathrm{Ca}-\mathrm{PT}$ & $5 \mathrm{ml} \mathrm{HCl}+0.5 \mathrm{ml} \mathrm{HF}$ & 1 \\
\hline La-PT & $5 \mathrm{ml} \mathrm{HCl}$ & 1 \\
\hline Nd-PT & $5 \mathrm{ml} \mathrm{HCl}$ & 1 \\
\hline Sm-PT & $5 \mathrm{ml} \mathrm{HCl}$ & 1 \\
\hline Gd-PT & $6 \mathrm{ml} \mathrm{HCl}$ & 1 \\
\hline PZT & $5 \mathrm{ml} \mathrm{HCl}+0.5 \mathrm{ml} \mathrm{HF}$ & 1 \\
\hline PLZT & $5 \mathrm{ml} \mathrm{HCl}+0.5 \mathrm{ml} \mathrm{HF}$ & 1 \\
\hline PMN & $5 \mathrm{ml} \mathrm{HCl}$ & 1 \\
\hline$\beta^{\prime}$-Sialon & - & - \\
\hline
\end{tabular}

reagents, the amount of impurities found is lower than the limit guaranteed by the manufacturer (Merck).

Table 9 shows the results obtained in the determination of the detection limits of the minor elements in the matrix corresponding to hydrochloric acid microwave-assisted decomposition $(5 \% \mathrm{HCl})$, in the matrix corresponding to alkali fusion in a graphite crucible $\left(4 \% \mathrm{HNO}_{3}+1 \% \mathrm{Li}_{2} \mathrm{~B}_{4} \mathrm{O}_{7}\right)$ and in the matrix corresponding to alkali fusion in a platinum crucible $\left(10 \% \mathrm{HCl}+0.54 \% \quad \mathrm{Na}_{2} \mathrm{CO}_{3} \%+0.46 \% \quad \mathrm{Na}_{2} \mathrm{~B}_{4} \mathrm{O}_{7}\right)$. For comparison, the values reported by Boumans ${ }^{48}$ are also shown. As can be seen, the detection limits obtained for all the elements, except $\mathrm{Na}$ and $\mathrm{K}$, with microwave-assisted dissolution are lower than those achieved with alkali fusion. This may be due to the fact that the matrix effect in microwave digestion is lower because the reagent blanks (only acids) are the simplest, or because these reagent blanks have less impurities, as mentioned previously. For the alkali elements, the detection limits which are achieved with fusion are lower owing to the increase in the emission intensity that these elements undergo because of the effect of the decrease in ionization which takes place in the presence of large amounts of easily ionizable elements. Moreover, when the values obtained experimentally are compared with the detection limits reported by Boumans ${ }^{48}$ it can be noted that for all the elements, except $\mathrm{Ca}, \mathrm{Mg}$ and $\mathrm{Na}$, the experimental values are lower.

Tables 10 and 11 show the results obtained in the determi-

Table 9 Detection limits $\left(\mathrm{ng} \mathrm{ml}^{-1}\right)$ obtained for some elements by ICP-AES in the dissolution of the advanced ceramic materials by acid microwave-assisted heating (matrix of $5 \% \mathrm{HCl}$ ) and by alkali fusion in a graphite crucible (matrix of $4 \% \mathrm{HNO}_{3}+1 \% \mathrm{Li}_{2} \mathrm{~B}_{4} \mathrm{O}_{7}$ ) and in a platinum crucible (matrix of $10 \% \mathrm{HCl}+0.54 \% \quad \mathrm{Na}_{2} \mathrm{CO}_{3}+0.46 \%$ $\mathrm{Na}_{2} \mathrm{~B}_{4} \mathrm{O}_{7}$ ). For comparison, the detection limits reported by Boumans ${ }^{48}$ are also given

\begin{tabular}{ccccc}
\hline Element & $\begin{array}{c}\text { Microwave-assisted } \\
\text { heating }\end{array}$ & $\begin{array}{c}\text { Graphite } \\
\text { crucible }\end{array}$ & $\begin{array}{c}\text { Platinum } \\
\text { crucible }\end{array}$ & Boumans ${ }^{48}$ \\
$\mathrm{Ca}$ & 0.17 & 0.22 & 0.24 & 0.13 \\
$\mathrm{Ce}$ & 4.69 & 5.24 & 5.58 & 32 \\
$\mathrm{Cu}$ & 1.47 & 1.73 & 1.87 & 3.6 \\
$\mathrm{Fe}$ & 2.10 & 2.38 & 2.51 & 3.4 \\
$\mathrm{Gd}$ & 8.72 & 9.25 & 11.7 & 13 \\
$\mathrm{~K}$ & 188 & 154 & 146 & - \\
$\mathrm{La}$ & 0.79 & 0.88 & 0.91 & 6.7 \\
$\mathrm{Mg}$ & 0.16 & 0.19 & 0.20 & 0.1 \\
$\mathrm{Mn}$ & 0.18 & 0.22 & 0.22 & 0.93 \\
$\mathrm{Na}$ & 65 & 56 & - & 46 \\
$\mathrm{Nd}$ & 32.7 & 35.9 & 41.1 & 71 \\
$\mathrm{P}$ & 7.08 & 7.3 & 7.00 & 51 \\
$\mathrm{Si}$ & 2.71 & 2.92 & 3.32 & 8 \\
$\mathrm{Sm}$ & 4.13 & 4.62 & 4.87 & 36 \\
$\mathrm{Sr}$ & 0.024 & 0.026 & 0.027 & 0.28 \\
$\mathrm{Zr}$ & 0.11 & 0.13 & 0.13 & 4.7 \\
\hline
\end{tabular}




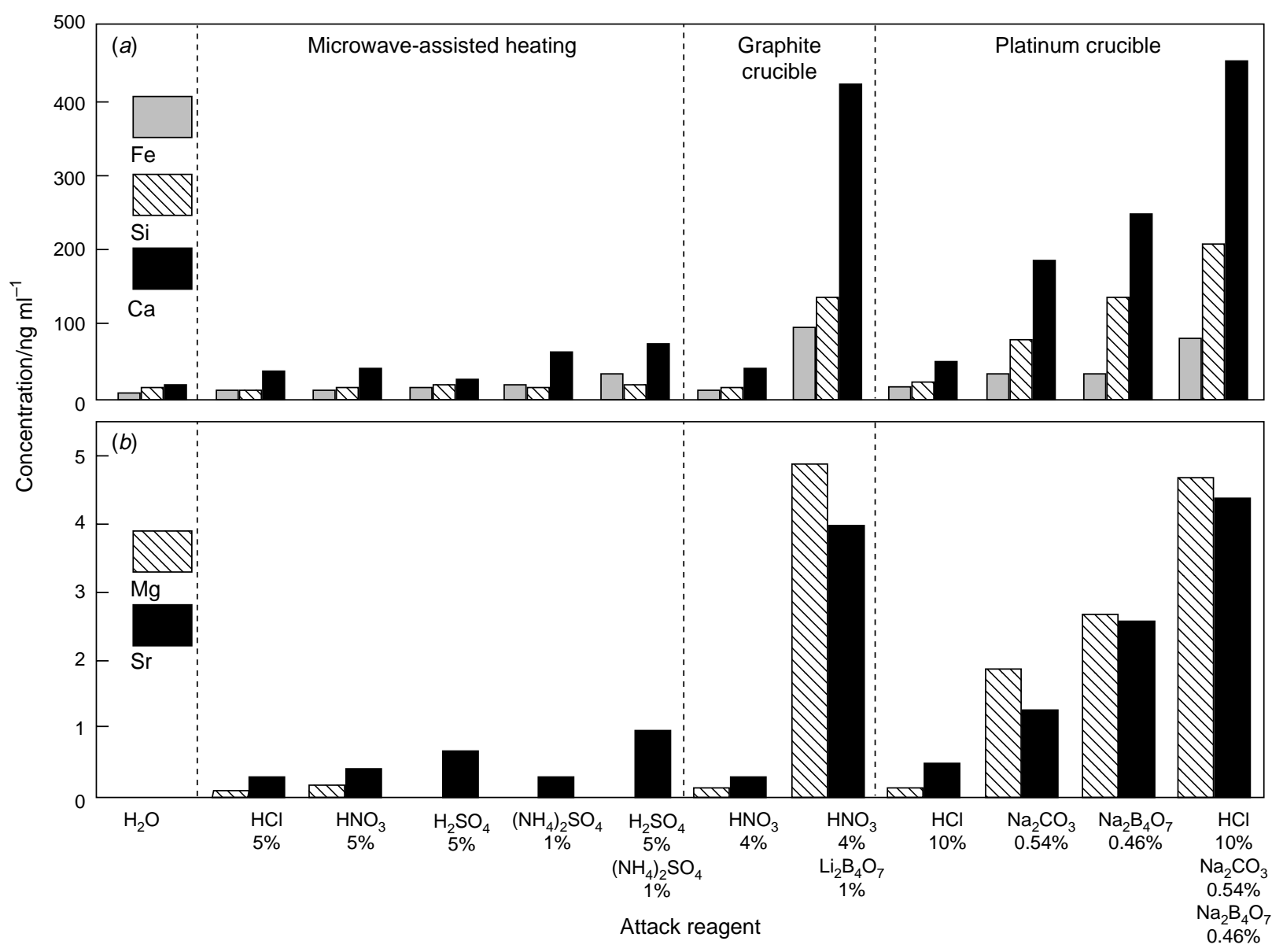

Fig. 3 Concentrations of $(a) \mathrm{Fe}, \mathrm{Si}$ and $\mathrm{Ca}$, and $(b) \mathrm{Mg}$ and $\mathrm{Sr}$ impurities found in some of the reagents used for the dissolution of the advanced ceramic materials by acid microwave-assisted heating and by alkali fusion with $\mathrm{Li}_{2} \mathrm{~B}_{4} \mathrm{O}_{7}$ in a graphite crucible and with $\mathrm{Na}_{2} \mathrm{CO}_{3}+\mathrm{Na}_{2} \mathrm{~B}_{4} \mathrm{O}_{7}$ in a platinum crucible.

nation by ICP-AES of the macro-constituents and impurities, respectively, in the Gd-PT ceramic after dissolution by microwave heating with $6 \mathrm{ml}$ of $\mathrm{HCl}$ following microwave method 1 (Table 8), by alkali fusion with $\mathrm{Li}_{2} \mathrm{~B}_{4} \mathrm{O}_{7}$ in a graphite crucible and by alkali fusion with $\mathrm{Na}_{2} \mathrm{CO}_{3}+\mathrm{Na}_{2} \mathrm{~B}_{4} \mathrm{O}_{7}$ in a platinum crucible. For the macro-constituents (Table 10), the theoretical content of the three elements is also included for comparison. As can be seen, the results obtained for each element with the three dissolution methods are in good agreement. In the case of the macro-constituents they are also completely coincident with their theoretical contents. The RSD values which correspond to previous analytical results for the macro-constituents and the impurities are also given in Tables 10 and 11. As can be seen, for the macro-constituents the RSD values obtained are $<1 \%$. For the impurities the RSD levels are generally between 1 and $10 \%$. Higher values are only obtained for elements which are present at a very low concentration, such as $\mathrm{K}$ and Sr. A remarkable aspect is that, for all the elements the RSD values obtained in the chemical analysis of samples dissolved by microwave-assisted digestion are much lower that those achieved by alkali fusion, i.e., the precision obtained for the analytical results is much higher. Moreover, the determination of macro-constituents and impurities was also carried out on the other advanced ceramic materials and the results obtained (which are not included here for space reasons) are similar to those achieved for the Gd-PT ceramic. Hence it can be affirmed that the previous comments are applicable to all the advanced ceramic materials tested.

\section{CONCLUSIONS}

Sintered advanced ceramics are very refractory and chemically resistant materials. Their dissolution, consequently very difficult, is classically carried out with extreme chemical treatments (elevated temperature, long time and/or high concentration of reagents) by conventional acid decomposition and alkali fusion procedures. In this work, it has been demonstrated that these materials can be also dissolved by microwave-assisted heating.

Table 10 Analytical results obtained in the determination of macro-constituents by ICP-AES in the Gd-PT ceramic after dissolution by microwave-assisted heating with $\mathrm{HCl}$ and by alkali fusion with $\mathrm{Li}_{2} \mathrm{~B}_{4} \mathrm{O}_{7}$ in a graphite crucible and with $\mathrm{Na}_{2} \mathrm{CO}_{3}+\mathrm{Na}_{2} \mathrm{~B}_{4} \mathrm{O}_{7}$ in a platinum crucible. For comparison, the theoretical composition of the sample is also given

\begin{tabular}{|c|c|c|c|c|c|c|c|}
\hline \multirow[b]{2}{*}{ Element } & \multicolumn{2}{|c|}{ Microwave-assisted heating } & \multicolumn{2}{|c|}{ Graphite crucible } & \multicolumn{2}{|c|}{ Platinum crucible } & \multirow[b]{2}{*}{ Theoretical (\%) } \\
\hline & Found $(\%)$ & $\mathrm{RSD}^{*}(\%)$ & Found $(\%)$ & $\mathrm{RSD}^{*}(\%)$ & Found $(\%)$ & $\mathrm{RSD}^{*}(\%)$ & \\
\hline $\mathrm{Gd}$ & 15.07 & 0.63 & 15.42 & 0.71 & 16.23 & 0.79 & 15.2 \\
\hline $\mathrm{Pb}$ & 58.09 & 0.52 & 57.27 & 0.61 & 56.09 & 0.68 & 56.3 \\
\hline $\mathrm{Ti}$ & 13.41 & 0.71 & 13.41 & 0.78 & 12.54 & 0.86 & 13.1 \\
\hline
\end{tabular}

$* n=3$. 
Table 11 Analytical results obtained in the determination of impurities by ICP-AES in the Gd-PT ceramic after dissolution by microwaveassisted heating with $\mathrm{HCl}$ and by alkali fusion with $\mathrm{Li}_{2} \mathrm{~B}_{4} \mathrm{O}_{7}$ in a graphite crucible and with $\mathrm{Na}_{2} \mathrm{CO}_{3}+\mathrm{Na}_{2} \mathrm{~B}_{4} \mathrm{O}_{7}$ in a platinum crucible

\begin{tabular}{|c|c|c|c|c|c|c|}
\hline \multirow[b]{2}{*}{ Element } & \multicolumn{2}{|c|}{$\begin{array}{c}\text { Microwave-assisted } \\
\text { heating }\end{array}$} & \multicolumn{2}{|c|}{$\begin{array}{l}\text { Graphite } \\
\text { crucible }\end{array}$} & \multicolumn{2}{|c|}{$\begin{array}{l}\text { Platinum } \\
\text { crucible }\end{array}$} \\
\hline & $\begin{array}{c}\text { Found } \\
(\%)\end{array}$ & $\begin{array}{c}\mathrm{RSD}^{*} \\
(\%)\end{array}$ & $\begin{array}{c}\text { Found } \\
(\%)\end{array}$ & $\begin{array}{c}\mathrm{RSD}^{*} \\
(\%)\end{array}$ & $\begin{array}{c}\text { Found } \\
(\%)\end{array}$ & $\begin{array}{c}\mathrm{RSD}^{*} \\
(\%)\end{array}$ \\
\hline $\mathrm{Ca}$ & 108 & 4.6 & 114 & 7.9 & 117 & 12.8 \\
\hline $\mathrm{Ce}$ & 420 & 1.4 & 427 & 2.1 & 418 & 2.9 \\
\hline $\mathrm{Cu}$ & 110 & 5.4 & 112 & 8.9 & 114 & 10.5 \\
\hline $\mathrm{Fe}$ & 122 & 4.9 & 131 & 8.4 & 126 & 6.3 \\
\hline K & 58 & 8.6 & 53 & 15.1 & 61 & 16.4 \\
\hline $\mathrm{La}$ & 90 & 3.3 & 94 & 5.3 & 87 & 6.9 \\
\hline $\mathrm{Mg}$ & 432 & 2.5 & 428 & 3.3 & 435 & 2.8 \\
\hline $\mathrm{Mn}$ & 3049 & 1.7 & 3038 & 2.7 & 3117 & 3 \\
\hline $\mathrm{Na}$ & 214 & 5.6 & 207 & 10.6 & - & - \\
\hline $\mathrm{Nd}$ & 192 & 3.1 & 203 & 5.4 & 200 & 4.5 \\
\hline $\mathrm{P}$ & 248 & 3.2 & 250 & 4 & 244 & 3.7 \\
\hline $\mathrm{Si}$ & 1450 & 2.1 & 1483 & 2.8 & 1462 & 2.6 \\
\hline $\mathrm{Sm}$ & 215 & 3.2 & 220 & 5.4 & 204 & 7.3 \\
\hline $\mathrm{Sr}$ & 9 & 11.1 & 8 & 25 & 10 & 20 \\
\hline $\mathrm{Zr}$ & 258 & 3.1 & 261 & 3.8 & 255 & 5.5 \\
\hline
\end{tabular}

$* n=3$.

Methods have been developed for the microwave-assisted dissolution of sintered bodies of a great variety of structural and electronic advanced ceramic materials. Evidently, these microwave methods are also applicable to the powders used as starting materials in the synthesis of such ceramics. These methods are simple (three stages maximum), fast (15-35 min digestion time) and mild (20-60\% of the maximum microwave oven power).

The authors acknowledge the Departamentos de Cerámica y Electrocerámica del Instituto de Cerámica y Vidrio (Departments of Ceramics and Electroceramics of the Institute of Ceramics and Glass), Consejo Superior de Investigaciones Científicas (Superior Council of Scientific Research), Madrid, Spain, for the synthesis of the samples.

\section{REFERENCES}

1 Advanced Technical Ceramics, ed. Somiya, S., Academic Press, San Diego, 1989.

2 Hutchins, G. A., Maher, G. H., and Ross, S. D., Am. Ceram. Soc. Bull., 1987, 66, 681.

3 Jayaratna, M., Yoshimura, M., and Somiya, S., J. Mater. Sci., 1987, 22, 2011.

4 Roy-Chowdhury, P., and Deshpande, S. B., J. Mater. Sci., 1987, 22, 2209.

5 Wu, S., and Brook, R. J., Trans. J. Br. Ceram. Soc., 1983, 82, 200.

6 Miranzo, P., and Moya, J. S., in Science of Ceramics, ed. Taylor, D., Institute of Ceramics, Stoke-on-Trent, 1988, vol. 14, pp. $243-248$

7 Ishizuka, T., Uwamino, Y., Tsuge, A., and Kamiyanagi, T., Anal. Chim. Acta, 1984, 161, 285.

8 Homeier, E. H., Kot, R. J., Bauer, L. J., and Genualdi, J. T., J. Anal. At. Spectrom., 1988, 3, 829.

9 Graule, T., Van Bohlen, A., Broekaert, J. A. C., Grallath, E., Klockenkämper, R., Tschöpel, P., and Tölg, G., Fresenius' Z. Anal. Chem., 1989, 335, 637.
10 Graule, T., Tschöpel, P., Grallath, E., Broekaert, J. A. C., and Tölg, G., Ceram. Forum Int./Ber., 1991, 68, 5.

11 Ishii, H., and Satoh, K., Talanta, 1982, 29, 243.

12 Martínez-Lebrusant, C., and Barba, F., Analyst, 1990, 115, 1335.

13 Fariñas, J. C., and Barba, M. F., J. Anal. At. Spectrom., 1992, 7, 869.

14 Marín, S. R., Cornejo, S. G., and Arriagada, L., J. Anal. At. Spectrom., 1994, 9, 93.

15 Nathansohn, S., and Czupryna, G., Spectrochim. Acta, Part B, 1983, 38, 317.

16 Fravek, M., Krivan, V., Gercken, B., and Pavel, J., Mikrochim. Acta, 1994, 113, 251.

17 Adelhelm, C., and Hirschfeld, D., Fresenius' J. Anal. Chem., 1992, 342, 125.

18 Dornemann, A., Kolten, K. H., and Rudan, D., Fresenius' Z. Anal. Chem., 1987, 326, 232.

19 Docekal, B., Broekaert, J. A. C., Graule, T., Tschöpel, P., and Tölg, G., Fresenius' J. Anal. Chem., 1992, 342, 113.

20 Franek, M., and Krivan, V., Fresenius' J. Anal. Chem., 1992, 342, 118.

21 Fariñas, J. C., and Barba, M. F., Appl. Surf. Sci., 1991, 50, 202.

22 Morikawa, H., and Ishizuka, T., Analyst, 1987, 112, 999.

23 Fariñas, J. C., and Barba, M. F., Mikrochim. Acta, 1989, III, 299.

24 Fariñas, J. C., and Barba, M. F., J. Anal. At. Spectrom., 1992, 7, 877.

25 Foner, H. A., Analyst, 1984, 109, 1469.

26 Carleer, R., Van Poucke, L. C., and François, J. P., Bull. Soc. Chim. Belg., 1986, 95, 385.

27 Van der Walt, T. N., and Strelow, F. W. E., Anal. Chem., 1985, 57, 2889.

28 Dolezal, J., Lenz, J., and Sulcek, Z., Anal. Chim. Acta, 1969, 47, 517.

29 Foner, H. A., Anal. Chem., 1984, 56, 856.

30 Hejduk, J., and Novak, J., Fresenius' Z. Anal. Chem., 1968, 234, 327.

31 Pollmann, D., Leis, F., Tölg, G., Tschöpel, P., and Broekaert, J. A. C., Spectrochim. Acta, Part B, 1994, 49, 1251.

32 Matusiewicz, H., Mikrochim. Acta, 1993, 111, 71.

33 Broekaert, J. A. C., Brandt, R., Leis, F., Pilger, C., Pollmann, D., Tschöpel, P., and Tölg, G., J. Anal. At. Spectrom., 1994, 9, 1063.

34 Stulik, K., Beran, P., Dolezal, J., and Opekar, F., Talanta, 1978 , 25, 363.

35 Parker, A., and Healy, C., Analyst, 1970, 95, 204

36 Kozuka, S., Yokote, Y., Abe, K., Hayashi, M., and Matsunaga, H., Fresenius' J. Anal. Chem., 1995, 351, 801.

37 Friese, K. C., and Krivan, V., Anal. Chem., 1995, 67, 354.

38 Davis, W. F., and Merkle, E. J., Anal. Chem., 1981, 53, 1139.

39 Docekal, B., and Krivan, V., J. Anal. At. Spectrom., 1992, 7, 521.

40 Pilger, C., Leis, F., Tschöpel, P., Broekaert, J. A. C., and Tölg, G., Fresenius' J. Anal. Chem., 1995, 351, 110.

41 Goto, K., Furukawa, M., and Shibata, S., Fresenius' Z. Anal. Chem., 1987, 327, 730.

42 Chigina, R. P., and Rudenko, V. P., Glass Ceram., 1977, 34, 334.

43 Kruidhof, H., Anal. Chim. Acta, 1978, 99, 193.

44 Introduction to Microwave Sample Preparation: Theory and Practice, ed. Kingston, H. M., and Jassie, L. B., American Chemical Society, Washington, DC, 1988.

45 Matusiewicz, H., and Sturgeon, R. E., Prog. Anal. Spectrosc., 1989, 12, 21.

46 Tatár, E., Varga, I., and Záray, G., Mikrochim. Acta, 1993, 111, 45.

47 Fariñas, J. C., Cabrera, H. P., and Larrea, M. T., J. Anal. At. Spectrom., 1995, 10, 511.

48 Boumans, P. W. J. M., Line Coincidence Tables for Inductively Coupled Plasma Atomic Emission Spectrometry, Pergamon Press, Oxford, 2nd edn., 1984. 